\title{
Stage II Differentiated Thyroid Gland Carcinoma Under 45 Years AJCC v7
}

National Cancer Institute

\section{Source}

National Cancer Institute. Stage // Differentiated Thyroid Gland Carcinoma Under 45

Years AJCC V7. NCI Thesaurus. Code C101541.

Stage II includes: Any T, Any N, M1. M1: Distant metastasis. (from AJCC 7th Ed.) 